$\begin{array}{r}\text { Phinisi Integration Review } \\ \text { Vol. 2, No.1, Februari 2019 Hal 114-123 } \\ \text { Website: http://ojs.unm.ac.id/pir } \\ \text { p-ISSN: 2614-2325 dan e-ISSN: 2614-2317 } \\ \hline\end{array}$

\title{
Pengaruh Pengelolaan Kelas, Pemanfaatan Sarana Dan Prasarana Terhadap Hasil Belajar IPS Pada Peserta Didik Di Kelas IV SDN Se-Kecamatan Belawa Kabupaten Wajo
}

\author{
Sitti Hajeriani ${ }^{(1),}$ \\ Program Pascasarjana Jurusan Ilmu Pengetahuan Sosial Universitas Negeri Makassar \\ email: hijrah.hhp@gmail.com
}

\begin{abstract}
Abstrak. Penelitian ini bertujuan untuk mengetahui (1) Besar pengaruh pengelolaan kelas terhadap hasil belajar IPS peserta didik di kelas IV SDN Kecamatan Belawa Kabupaten Wajo, (2) Besar pengaruh pemanfaatan sarana terhadap hasil belajar IPS peserta didik di kelas IV SDN Kecamatan Belawa Kabupaten Wajo, (3) Adanya hubungan determinan positif antara pengaruh pengelolaan kelas, pemanfaatan sarana dan prasarana terhadap hasil belajar IPS pada peserta didik di kelas IV SDN Kecamatan Belawa Kabupaten Wajo. Penelitian ini menggunakan pendekatan penelitian deskriptif kuantitatif jenis regresi. Teknik pengumpulan data yang digunakan dalam penelitian ini adalah teknik kuisioner dan buku laporan peserta didik setiap semester atau nilai ulangan tengan semester. Teknik analisis data yang digunakan adalah statistik deskriptif. Instrumen penelitian berupa angket yang telah di validasi oleh validator, sedangkan metode analisis data menggunakan analisis regresi linear berganda. Hasil penelitian mengungkapkan bahwa : (1) Berdasarkan hasil uji T diperoleh besar pengaruh pengelolaan kelas terhadap hasil belajar IPS kelas IV SDN Kecamatan Belawa Kabupaten Wajo sebesar 93,12\%, (2) Besar pengaruh pemanfaatan sarana dan prasarana berpengaruh terhadap hasil belajar IPS kelas IV SDN Kecamatan Belawa Kabupaten Wajo sebesar -27,6\%, (3) Hasil uji T menunjukkan Pengelolaan kelas sangat determinan terhadap hasil belajar IPS pada peserta didik di kelas IV SDN se-Kecamatan Belawa Kabupaten Wajo sebesar (93,12\%), sedangkang pemanfaatan sarana dan prasarana mempunyai pengaruh sebesar $-27,6 \%$. Berdasarkan hasil penelitian ini dapat ditarik kesimpulan bahwa ada pengaruh pengaruh pengelolaan kelas, pemanfaatan sarana dan prasarana terhadap hasil belajar IPS pada peserta didik di kelas IV SDN Kecamatan Belawa Kabupaten Wajo.
\end{abstract}

Kata Kunci: Pengelolaan Kelas; Pemanfaatan Sarana; Hasil Belajar.

Abstract. The study aims at examining (1) the influence of classroom management on Social Sciences (IPS) learning outcomes of grade IV students at SDN (public elementary schools) in Belawa Subdistrict In Wajo District, (2) the extent of the influence of utilizing facility on IPS learning outcomes of grade IV students at SDN (public elementary schools) in Belawa Subdistrict In Wajo District, and (3) There is a relationship between a positive determinant between the influence of classroom management, the use of facilities and infrastructure on social studies learning outcomes in students in grade IV SDN Belawa District, Wajo District. The study employed desctiptive quantitative research with regression type. Data were colleted by using questionnaire and report book of students in each semester of the final semester score. The data analysis employed in this study was descriptive statistics. The research instrument in terms of questionnaire had been validated by the assessors; wheres, analysis method used multiple linear regressions. The 
results of the study revealed that: (1) Based on the results of the T test, the effect of class management on social studies learning outcomes in the fourth grade of SDN Belawa Subdistrict Wajo District was $93.12 \%$, (2) The influence of the use of facilities and infrastructure affected the fourth grade social studies learning outcomes SDN Belawa District, Wajo Regency amounted to $-27.6 \%$, (3) The results of the T test showed Class management was very determinant of social studies learning outcomes in students in grade IV of SDN in Belawa District, Wajo District at (93.12\%), utilization utilization facilities and infrastructure have an influence of $-27.6 \%$. Based on the results of this study, it can be concluded that there is an influence of class management, the use of facilities and infrastructure on social studies learning outcomes in students in grade IV SDN Belawa District, Wajo District.

Keywords: Classroom Management; Utilization of Learning Facilities; Results

Ini adalah artikel dengan akses terbuka dibawah licenci CC BY-NC-4.0

(https://creativecommons.org/licenses/by-nc/4.0/ ).

\section{PENDAHULUAN}

Pendidikan merupakan faktor penting bagi kemajuan suatu bangsa. Hal tersebut tertera dalam UU Nomor 20 Tahun 2003 tentang Sistem Pendidikan Nasional yang menjelaskan tentang fungsi pendidikan nasional yaitu mengembangkan kemampuan dan membentuk watak serta peradaban bangsa yang bermartabat dalam rangka mencerdaskan kehidupan bangsa, bertujuan untuk berkembangnya potensi peserta didik agar menjadi manusia yang beriman dan bertakwa kepada Tuhan Yang Maha Esa, berakhlak mulia, sehat, berilmu, cakap, kreatif, mandiri, dan menjadi warga negara yang demokratis serta bertanggung jawab. Untuk menjamin tercapainya fungsi dan tujuan pendidikan tersebut, perlu adanya standar nasional pendidikan. Dengan demikian, pemerintah telah mengamanatkan penyusunan delapan standar nasional pendidikan sebagaimana diatur dalam Peraturan Pemerintah Republik Indonesia No. 19 Tahun 2005 tentang Standar Nasional Pendidikan.

Tercapainya tujuan pembelajaran perlu adanya tindakan yang dapat mewujudkan terciptanya suasana kelas yang optimal. Pengelolaan kelas dilihat dari dua segi yaitu pengelolaan yang menyangkut peserta didik (pengaturan peserta didik) dan pengelolaan sarana dan prasarana. Contoh pengaturan peserta didik (Kondisi Emosional) yaitu tingkah laku, kedisiplinan, minat/ Perhatian, gairah belajar dan dinamika kelompok. Sedangkang pengelolaan sarana dan prasarana meliputi ventilasi, pencahayaan kenyamanan, penataan ruangan kelas, pengaturan waktu, penggunan media pembelajaran, penggunaan alat-alat pembelajaran, ruang pendidikan, dan ruangan penunjang yang mendukung proses pendidikan misalnya kantin.

Guru megalami dua masalah dalam pengelolaan yaitu masalah pengajaran dan masalah pengelolaan. Masalah pengajaran adalah usaha membantu anak didik dalam mencapai tujuan khusus pengajaran berlangsung, membuat suatu pelajaran, penyajian informasi, mengajukan pertanyaan, evalasi dan masih banyak lagi. Sedangkan masalah pengelolaan adalah usaha menciptakan dan mempertahankan kondisi yang sedemikian rupa sehingga proses belajar dapat berlangsung secara efektif. Pengelolaan kelas yang baik memungkinkan sang guru mengajar dengan baik, karena kelas yang terhindar dari konflik yang memungkinkan guru mengembangkan apa-apa yang diinginkannya. 
Sarana dan prasarana dalam pembelajaran sangatlah diperlukan dalam menunjang keberhasilan proses pembelajaran, memilih dan menentukan sarana dan prasarana pembelajaran dalam rangka mendorong keinginan merupakan tugas guru, sehingga dengan adanya sarana dan prasarana yang memadai sesuai dengan standar sarana dan prasarana sekolah kemungkinan peserta didik dapat termotivasi untuk belajar mengikuti pembelajaran, yang pada gilirannya mampu meningkatkan hasil belajar peserta didik.

Berdasarkan observasi yang dilakukan di salah satu SDN Kecamatan Belawa Kabupaten Wajo, peneliti mengamati setiap guru yang masuk ke dalam kelas. Maka pada saat yang bersamaan, guru tersebut menghadapi dua masalah pokok; 1) masalah pengelolaan kelas, 2) masalah pemanfaatan sarana dan prasarana dalam proses pembelajaran. Pengelolaan kelas yang dilakukan oleh guru belum dilakukan secara maksimal. Ketika kegiatan belajar mengajar berlangsung, guru masih melaksanakan pembelajaran dengan suasana kelas yang monoton, belum ada variasi dalam kegiatan belajar mengajar.

\section{Pengertian Hasil Belajar}

Sasaran dari kegiatan belajar mengajar adalah hasil belajar. Apabila proses belajar mengajar berjalan baik, maka hasil belajar juga baik. Artinya hasil belajar harus bisa dimanfaatkan sebaik-baiknya oleh pengajar dalam menyelesaikan suatu masalah dan sebagai pertimbangan dalam langkah selanjutnya. Hasil belajar adalah prestasi yang dicapai oleh peserta didik setelah mengikuti proses belajar mengajar yang berkenaan dengan materi suatu pelajaran. Soemantri (Sumoharjo: 2015) mengatakan bahwa hasil belajar merupakan suatu indikator dari perubahan yang terjadi pada diri peserta didik setelah mengalami proses belajar.

Gagne (Ainurrahman, 2010: mengemukakan ada lima macam hasil belajar, yaitu: (a) Keterampilan intelektual, atau pengetahuan prosedural yang mencakup belajar konsep, prinsip dan pemecahan masalah yang diperoleh melalui penyajian materi di sekolah, (b) Strategi kogmitif, yaitu kemampuan untuk memecahkan masalah-masalah baru dengan jalan mengatur proses internal masing-masing individu dalam memperhatikan, belajar, mengingat, dan berpikir, (c) Informasi verbal, yaitu kemampuan kemampuan untuk mendeskripsikan sesuatu dengan kata-kat dengan jalan mengatur informasi-informasi yang relevan, (d) Keterampilan motorik, yaitu kemampuan untuk melaksanakan dan mengkoordinasikan gerakan-gerakan yang berhubungan dengan otot, (e) Sikap, yaitu suatu kemampuan internal yang mempengaruhi tingkah laku seseorang yang didasari oleh emosi, kepercayaan-kepercayaan serta faktor intelektual.

\section{Pengelolaan Kelas}

Secara istilah, pengelolaan kelas berasal dari bahasa inggris "Classroom Management". Classroom berarti kelas sedangkan Management berarti kepemimpinan, ketatalaksanaan, penguasaan maupun pengurusan. Secara umum dari segi didaktis menurut Sri Anitah Wiryawan \& Noorhadi. (Tri Mulyani. W, 2001: 6) kelas diartikan sebagai sekelompok peserta didik yang pada waktu yang sama menerima pelajaran yang sama dari guru yang sama. Pengelolaan kelas diartikan sebagai kepemimpinan ataupun ketatalaksanaan guru dalam praktek penyelenggaraan kelas (Tri Mulyani. W, 2001: 5). Sependapat dengan hal tersebut Moh. Uzer Usman (2006: 97) mengemukakan bahwa "pengelolaan kelas adalah keterampilan guru untuk menciptakan dan memelihara kondisi belajar yang optimal dan mengembalikannya bila terjadi gangguan dalam proses belajar mengajar".

\section{Pengertian Sarana dan Prasarana Pendidikan}

Dalam Permendiknas No. 24 Tahun 2007 menyebutkan sarana adalah perlengkapan pembelajaran yang dapat dipindah-pindah sedangkan prasarana adalah fasilitas dasar untuk menjalankan fungsi sekolah/madrasah. Pendapat lain, Bafadal (2008:2) menyatakan bahwa sarana pendidikan adalah semua perangkat peralatan, bahan dan perabot yang secara langsung digunakan dalam proses pendidikan di sekolah sedangkan prasarana 
pendidikan adalah semua perangkat kelengkapan dasar yang secara tidak langsung menunjang pelaksanaan proses pendidikan di sekolah.

\section{Macam-macam sarana dan prasarana}

Sehubungan dengan sarana belajar mengajar atau pendidikan, Ibrahim Bafadal (Nawawi,2013:2-3) mengklasifikasikannya menjadi beberapa macam sarana pembelajaran, yaitu ditinjau dari sudut: (1) habis tidaknya dipakai; (2) bergerak tidaknya pada saat digunakan; dan (3) hubungannya dengan proses belajar mengajar.

\section{Tinjauan IPS}

Banks (Ahmad Susanto 2012: 141) pendidikan IPS atau yang dia sebut social studies, merupakan bagian dari kurikulum di sekolah yang bertujuan untuk membantu mendewasakan peserta didiksupaya dapat mengembangkan pengetahuan, keterampilan, sikap, dan nilai-nilai dalam rangka berpartisipasi di dalam masyarakat, negara, dan bahkan di dunia. Banks menekankan begitu pentingnya pendidikan IPS diterapkan di sekolah-sekolah, mulai dari tingkat dasar sampai keperguruan tinggi, terutama di sekoalah dasar dan menengah

Menurut Gross (Etin Solihatin, dkk, 2009: 14) tujuan ilmu pengetahuan sosial adalah untuk mempersiapkan peserta didik menjadi warga negara yang baik dalam kehidupannya di masyarakat dan untuk mengembangkan kemampuan peserta didik menggunakan penalaran dalam mengambil keputusan dari setiap masalah yang dihadapi.

\section{METODE PENELITIAN}

\section{Jenis Penelitian}

Menurut Creswell (2010: 24) terdapat tiga macam pendekatan penelitian, yaitu pendekatan kuantitatif, pendekatan kualitatif dan pendekatan metode campuran. Sesuai dengan judul penelitian dan tujuan penelitian, maka data penelitian yang diperoleh berupa data angka-angka, maka penelitian ini menggunakan pendekatan Kuantitatif.

\section{Variabel Penelitian}

Variabel dalam Penelitian ini terdiri dari atas 3 variabel yang terbagi atas 2 variabel independent (bebas) yakni pengelolaaan Kelas (X1) dan pemanfaatan sarana dan prasarana (X2), Variabel terikat dalam penelitian ini adalah hasil belajar IPS peserta didik (Y).

\section{Definisi Operasional Variabel}

a. Pengelolaan kelas $\left(\mathrm{X}_{1}\right)$. Indikatorindikator dari pengelolaan kelas antara lain Pendekatan pengelolaan kelas, prinsip-prinsip pengelolaan kelas dan keterampilan mengelolah kelas. Pengelolaan kelas ini dapat diukur dengan menggunakan kuisioner yang di isi langsung oleh peserta didik.

b. Pemanfaatan sarana dan prasarana $\left(\mathrm{X}_{2}\right)$ meliputi ventilasi, pencahayaan kenyamanan, penataan ruangan kelas, penggunan media pembelajaran, penggunaan alat-alat pembelajaran, ruang pendidikan, ruangan penunjang yang mendukung proses pendidikan misalnya kantin.

c. Hasil belajar IPS (Y) yang dimaksud adalah hasil tes sumatif yang dapat dilihat pada rata-rata yang dicapai oleh anak peserta didik dari mata pelajaran IPS yang dapat dilihat dalam buku raport.

\section{Desain penelitian}

Desain penelitian merupakan suatu rancangan yang digunakan untuk mempermudah proses penelitian. Adapun desain yang digunakann dalam penelitian ini digambarkan sebagai berikut:

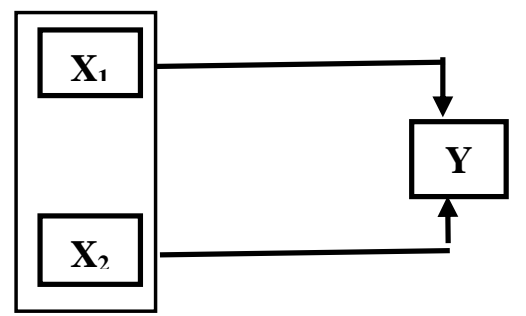


Gambar 3.1 Diagram Variabel

Keterangan:

$\mathrm{X}_{1}=$ Pengelolaan Kelas

$\mathrm{X}_{2}=$ Pemanfaatan Sarana dan

prasarana

$\mathrm{Y}=$ Hasil Belajar IPS

$\rightarrow=$ Mempengaruhi

\section{Populasi dan Sampel}

\section{a. Populasi}

Sugiyono (2015:80) "Poulasi adalah wilayah generalisasi yang terdiri atas : Objek/subjek yang mempunyai kualitas dan karakteristik tertentu yang ditetapkan oleh peneliti untuk di pelajari dan kemudian ditarik kesimpulannya

\section{b. Sampel}

Menurut Abustam, (2006:39) sampel adalah sebagian sari unit-unit yang ada daalam populasi yang ciri-ciri atau karakteristiknya benar-benar diselidiki. Dalam pengambilan sampel penelitian ini menggunakan teknik Cluster Sampling (Area Sampling) Belawa Kabupaten Wajo Tahun 2016/2017

\section{Teknik Pengumpulan Data}

Teknik pengumpulan data menurut Noor (2012:138) merupakan cara mengumpulkan data yang dibutuhkan untuk menjawab rumusan masalah penelitian. Teknik pengumpulan data dalam penelitian ini dikumpulkan melalui teknik kuisioner dan buku laporan peserta didik setiap semester atau nilai ulangan akhir semester.

\section{Instrumen Penelitian}

Instrumen atau alat pengumpul data yang digunakan dalam penelitian ini adalah buku laporan peserta didik setiap semester untuk melihat hasil belajar IPS Peserta didik dan kuesioner (angket) untuk pengelolaan kelas dan pemanfaatan sarana dan prasarana. Dalam memperoleh data mengenai variabel yang diteliti, maka digunakan instrumen penelitian. Instrumen yang digunakan dalam penelitian ini berupa : Observasi, Angket Kuesioner (angket), Dokumentasi

\section{Teknik Analisis Data}

Data yang sudah terkumpul dianalisis menggunakan dua macam teknik statistik, yaitu teknik statistik deskriptif dan teknik statistik infrensial. Beberapa persyaratan yang perlu diuji sebelumnya diantaranya berupa uji normalitas, multikoliniaritas, heteroskedastisitas, autokorelasi

\section{HASIL DAN PEMBAHASAN}

Hasil

\section{Analisis Statistik Deskriptif \\ a) Diskripsi Variabel Pengelolaan Kelas Pengelolaan Kelas}

Berdasarkan Diskripsi Variabel Pengelolaan Kelas Pengelolaan Kelas (X1) pada Guru mata pelajaran IPS di SDN Sekecamatan Belawa Kabupaten Wajo, sebanyak 52,84\% Peserta didik menyatakan "Sangat Sering" pendidik mata pelajaran IPS melakukan pengelolaan kelas pada saat proses pembelajaran, sebanyak 23,92\% Peserta didik menyatakan "Sering", 10,22\% Peserta didik yang masih "Ragu-Ragu", $6,62 \% \%$ Peserta didik menyatakan "Tidak Sering" dan 6,38\% Peserta didik menyatakan "Sangat Tidak Sering" pendidik mata pelajaran IPS melakukan pengelolaan kelas pada saat proses pembelajaran. Berdasarkan table diatas dapat disimpulkan bahwa dengan adanya pengelolaan kelas yang di lakukan oleh guru mata pelajaran IPS dapat menghindari hal-hal yang mengganggu kenyamanan kelas.

\section{b) Diskripsi Variabel Pemanfaatan Sarana dan Prasarana}

Berdasarkan tabel diatas, dapat diketahui bahwa Pemanfaatan Sarana dan Prasarana (X1) pada Guru mata pelajaran IPS di SDN Sekecamatan Belawa Kabupaten Wajo, sebanyak 55,16\% Peserta didik menyatakan "Sangat Sering", sebanyak 18,46\% Peserta didik menyatakan "Sering", 6,91\% "RaguRagu", $8,82 \%$ peserta didik menyatakan "Tidak Sering" pendidik mata pelajaran IPS memanfaatkan sarana dan prasarana di lingkungan sekolah pada saat proses pembelajaran dan sebanyak $10,62 \%$ peserta 
didik menyatakan "Sangat Tidak Sering" pendidik mata pelajaran IPS melakukan pengelolaan memanfaatkan sarana dan prasarana kelas pada saat proses pembelajaran. Berdasarkan tabel diatas dapat disimpulkan bahwa dengan memanfaatkan sarana dan prasarana di sekolah memungkinkan peserta didik dapat termotivasi untuk terus belajar

\section{c) Distribusi Frekuensi Hasil Belajar}

Berdasarkan tabel di atas, Frekuensi hasil belajar peserta didik sebanyak 2 orang berada pada peringkat I sebesar $4,87 \%$, Frekuensi hasil belajar peserta didik sebanyak 2 orang pada peringkat II sebesar $4,87 \%$, Frekuensi hasil belajar peserta didik sebanyak 5 orang pada Peringkat III sebesar $12,19 \%$, frekuensi hasil belajar peserta didik sebanyak 5 orang pada peringkat IV sebesar $12,19 \%$, frekuensi hasil belajar peserta didik sebanyak 3 orang pada peringkat $\mathrm{V}$ sebesar 7,31\% dan frekuensi hasil belajar peserta didik sebanyak 17 orang pada peringkat VI sebesar $41,46 \%$.

\section{Analisis Statistik Inferensial}

\section{1) Hasil Analisis Regresi Linier Berganda}

Berdasarkan hasil Analisis Regresi Linier Berganda Variabel terikat (dependen) pada regresi ini adalah $\mathrm{Y}$ sedangkan variabel bebasnya adalah $\mathrm{X}_{1}$ dan $\mathrm{X}_{2}$. Berdasarkan tabel diatas maka dapat dibuat model persamaan regresi dituliskan sebagai berikut: $\mathrm{Y}=78.451+0.056 \mathrm{X}_{1}+(-0,065) \mathrm{X}_{2}$. Nampak pada persamaan tersebut menunjukkan angka yang signifikan pada variabel $\mathrm{X}_{1}$ dan $\mathrm{X}_{2}$. Adapun interprestasi dari persamaan tersebut adalah:

a. Konstanta $=$ Nilai konstanta (a) adalah 78,451. Artinya jika pengelolaan kelas , dan pemanfaatan sarana dan prasarana nilainya adalah 0 maka hasil belajar nilainya negative.

b. $\mathrm{B} 1$ = Nilai koefisien regresi variabel pengelolaan kelas (b1) bernilai positif yaitu 0.056. Artinya bahwa setiap peningkatan pengelolaan kelas sebesar 1,00 maka hasil belajar juga akan meningkat sebesar 0.056 dan sebaliknya jika pengelolaan kelas turun 1.00 maka hasil belajar akan turun sebanyak 0.056 .

c. $\mathrm{B} 2$ = Nilai koefisien regresi variabel pemanfaatan sarana dan prasarana (b2) sebesar -0,065. Koefisien bernilai negative artinya jika tidak ada pemanfaatan sarana dan prasarana maka hasil belajar akan mengalami penurunan (negatif).

2) Uji Hipotesis

a. Pengujian Secara Persial

Uji $\mathrm{T}$ digunakan untuk mengetahui ada tidaknya pengaruh pervariabel bebas terhadap variabel terikat yaitu variabel pengelolaan kelas dan pemanfaatan sarana dan prasarana terhadap hasil belajar peserta didik secara persial

a) Pengaruh Antara Pengelolaan Kelas Terhadap Hasil Belajar Peserta Didik

Dari hasil pengujian hipotesis menggunakan uji parsial (Uji t) diperoleh $t$ hitung sebesar 1,932 dengan nilai signifikansinya 0,061 . Hal ini sesuai dengan kriteria pengujian menunjukkan bahwa $\mathrm{t}$ hitung > t tabel yakni 1,932 > 1.683 dengan tingkat signifikansinya $0,061<0,05$ dengan demikian dapat disimpulkan bahwa Ho ditolak atau $\mathrm{Ha}$ diterima. Hal ini menunjukkan bahwa secara parsial (individual) hipotesis Hal berbunyi "Ada pengaruh positif yang signifikan antara pengelolaan kelas terhadap hasil belajar IPS peserta didik kelas IV di SDN Sekecamatan Belawa Kabupaten Wajo.” Diterima.

b) Pengaruh Pemanfaatan Sarana Dan Prasarana Terhadap Hasil Belajar Peserta Didik

Hasil hipotesis menggunakan uji parsial (uji t) diperoleh $\mathrm{t}$ hitung sebesar (-2.764) dengan nilai signifikansinya 0,000 . Hal ini sesuai dengan kriteria pengujian menunjukkan bahwat $\mathrm{t}$ hitung $<\mathrm{t}$ tabel yakni 
$-2.764<\quad 1.683$ dengan tingkat signifikansinya $0,009<0,05$ dengan demikian dapat disimpulkan bahwa $\mathrm{Ho}_{2}$ diterima atau $\mathrm{Ha}_{2}$ ditolak. Oleh karena itu dari hasil tersebut memperlihatkan bahwa variabel pemanfaatan sarana dan prasarana berpengaruh negatif terhadap hasil belajar IPS peserta didik

\section{b. Pengujian Secara Simultan}

Pengujian menggunakan Uji $\mathrm{F}$ dalam penelitian ini dimaksudkan untuk menguji signifikansi hipotesis secara simultan variabel pengelolaan kelas, pemanfaatan sarana dan prasarana terhadap hasil belajar.

pengujian hipotesis menggunakan uji simultan (uji F) diperoleh $\mathrm{F}$ hitung $(4,178)$ dengan nilai signifikansinya 0,023 . Hal ini sesuai dengan kriteria pengujian menunjukkan $\mathrm{F}$ hitung $>\mathrm{F}$ tabel yakni $4.178>3,24$ sedangkan signifikansi $(0,023)$ dari alpha taraf $5 \%$ atau 0,05 sehingga $\mathrm{Ha}$ yang berbunyi "Ada pengelolaan kelas, pemanfaatan sarana dan prasarana terhadap hasil belajar IPS pada peserta didik di kelas IV SDN se-Kecamatan Belawa Kabupaten Wajo " dan hipotesis secara simultan diterima.

\section{Pembahasan}

\section{a. Pengaruh Antara Pengelolaan Kelas Terhadap Hasil Belajar Peserta Didik.}

Dari hasil pengujian hipotesis yang telah tertera pada hasil pnelitian menggunakan uji parsial (Uji t) diperoleh $\mathrm{t}$ hitung sebesar 1,932 dengan nilai signifikansinya 0,061 . Hal ini sesuai dengan kriteria pengujian menunjukkan bahwa $\mathrm{t}$ hitung $>\mathrm{t}$ tabel yakni 1,932 > 1.683 dengan tingkat signifikansinya $0,061<0,05$ dengan demikian dapat disimpulkan bahwa Ho ditolak atau $\mathrm{Ha}$ diterima. Hal ini menunjukkan bahwa secara parsial (individual) hipotesis Hal berbunyi "Ada pengaruh positif yang signifikan antara pengelolaan kelas terhadap hasil belajar IPS peserta didik kelas IV di SDN Sekecamatan Belawa Kabupaten Wajo.” Diterima.
Hal ini sejalan dengan pengertian umum pngelolaan kelas bahwa pengelolaan kelas merupakan suatu kemampuan yang dimiliki oleh guru dalam menciptakan, mengkondisikan serta mengembalikan suasana kelas dan belajar peserta didik yang efektif agar tetap menyenangkan dan optimal. Pengelolaan kelas yang efektif merupakan prasyarat mutlak bagi terjadinya proses belajar mengajar yang efektif (Syaiful Bahri Djamarah \& Aswan Zain, 2002: 195). Berdasarkan pernyataan tersebut, dalam suatu pembelajaran diperlukan adanya pengelolaan kelas yang efektif serta optimal.

Hasil pnelitian di atas juga diperkuat oleh tujuan Pengelolaan kelas dilakukan agar suasana belajar di kelas tetap menyenangkan. Adapun tujuan pegelolaan kelas menurut Sudirman (Syaiful Bahri Djamarah, 2002: 199) adalah penyediaan fasilitas bagi bermacam-macam kegiatan belajar peserta didik dalam lingkungan sosial, emosional, dan intelektual dalam kelas. Fasilitas yang disediakan tersebut akan berpengaruh pada terciptanya suasana sosial yang memberikan kepuasan, suasana disiplin, dan perkembangan intelektual.

\section{b. Pengaruh Pemanfaatan Sarana Dan Prasarana Terhadap Hasil Belajar Peserta Didik}

Berdasarkan hasil hasil hipotesis pada bab sebleumnya menggunakan uji parsial (uji t) diperoleh $t$ hitung sebesar $(-2,764)$ dengan nilai signifikansinya 0,000 . Hal ini sesuai dengan kriteria pengujian menunjukkan bahwat $\mathrm{t}$ hitung $>\mathrm{t}$ tabel yakni $-2,764>1.683$ dengan tingkat signifikansinya $0,009<0,05$ dengan demikian dapat disimpulkan bahwa $\mathrm{Ho}_{2}$ ditolak atau $\mathrm{Ha}_{2}$ diterima. Oleh karena itu dari hasil tersebut memperlihatkan bahwa variabel pemanfaatan sarana dan prasarana berpengaruh negatif terhadap hasil belajar IPS peserta didik. Meskipun hasil penelitian di atas pada uji $t$ bernilai negatif namun bukan berarti tidak ada pengaruh pemanfaatan sarana dan prasarana terhadap hasil belajar peserta didik, dan pada 
penelitian diatas berpengaruh negatif bukan berarti berdampak negatif antara $\mathrm{X} 2$ terhadap $\mathrm{Y}$, karena nilai signifikan lebih kecil dari 0.05 itu berarti ada pengaruh yang sinifikan antara variabe $\mathrm{X} 2$ dan Variabel Y. Hasil penelitian diatas sejalan dengan pengertian Sarana dan prasarana pendidikan merupakan material pendidikan yang sangat penting. Sekolah yang memiliki sarana dan prasarana pendidikan yang lengkap sangat menunjang proses pendidikan di sekolah. Baik guru maupun peserta didik, merasa terbantu dengan adanya fasilitas tersebut.

Menurut Roestiyah (2004: 166) Pemanfaatan sarana belajar yang baik akan memudahkan anak dalam melakukan aktivitas belajar sehingga anak lebih semangat dalam belajar. Sebaliknya, dengan kurangnya sarana belajar akan mengakibatkan anak kurang bersemangat dan kurang bergairah dalam belajar. Hal ini tentu saja akan mempengaruhi hasil belajar anak.

Sebagaimana dikemukakan Hamalik (2003: 37) bahwa pemakaian media pengajaran (sarana prasarana pembelajaran) dalam proses belajar mengajar dapat membangkitkan keinginan dan minat yang baru membangkitkan motivasi dan rangsangan kegiatan belajar, dan bahkan membawa pengaruh psikologis terhadap siswa. Penggunaan media pengajaran pada tahap orientasi pengajaran akan sangat membantu keefektifan proses pembelajaran dan penyampaian pesan dan isi pelajaran pada saat itu. Di samping membangkitkan motivasi dan minat siswa, media pengajaran juga dapat membantu siswa meningkatkan pemahaman, menyajikan data dengan menarik dan terpercaya, memudahkan penafsiran data, dan memadatkan informasi

\section{c. Determinan Pengelolaan Kelas, Pemanfaatan Sarana Dan Prasarana Terhadap Hasil Belajar.}

Hasil pengujian hipotesis mengenai pengelolaan kelas dengan menggunakan uji parsial (uji t) diperoleh $\mathrm{T}$ hitung sebesar 1,932 atau 93,21\% dengan signifikan lebih kecil 0,061, sedangkan uji hipotesis pemanfaatan sarana dan prasarana diperoleh $\mathrm{T}$ hitung sebesar $-4,327$ atau $32,47 \%$ dengan signifikan lebih kecil 0,009. Dengan demikian dapat disimpulkan bahwa yang paling determinan terhadap hasil belajar IPS se-Kecamatan Belawa Kabupaten Wajo adalah pengelolaan kelas.

Hasil penelitian diatas bahwa Pengelolaan kelas merupakan keterampilan yang dilakukan oleh guru menciptakan serta mengkondisikan suasana kelas tetap kondusif dan menyenangkan. Suatu kelas akan terasa menyenangkan apabila terdapat suatu pengelolaan yang baik yang dilakukan oleh guru. Peserta didik juga akan merasa nyaman saat mengikuti pembelajaran apabila suasana kelas tetap kondusif.

Tujuan pengelolaan kelas secara umum adalah untuk menciptakan kondisi dalam kelompok kelas yang berupa lingkungan yang baik. Selain itu, menurut Sudirman (Syaiful Bahri Djamarah \& Aswan Zain, 2002: 199-200) menyatakan bahwa tujuan pengelolaan kelas secara fisik adalah untuk menyediakan fasilitas guna berbagai macam kegiatan belajar peserta didik dalam lingkungan sosial, emosional, dan intelektual dalam kelas. Dengan adanya fasilitas tersebut memungkinkan peserta didik untuk belajar serta terciptanya suasana sosial yang memberikan kepuasan, disiplin, perkembangan intelektual, emosional serta apresiasi pada peserta didik. Penyediaan fasilitas atau sarana dan prasarana termasuk dalam pengelolaan kelas secara fisik. Hal ini sejalan dengan penelitian Husna (2013) yang menyatakan bahwa dengan tingginya penciptaan iklim kelas maka akan semakin 
menunjang dalam pemenuhan kebutuhan peserta didik terutama kebutuhan belajar dengan iklim kelas yang kondusif. Untuk menunjang tingginya penciptaan iklim kelas yang kondusif, maka harus ditunjang pula dengan fasilitas yang menyenangkan, seperti: sarana prasarana, pengaturan lingkungan kelas, pengaturan lingkungan sekolah, penampilan dan sikap guru, serta hubungan yang harmonis baik antara guru dengan peserta didik dan antara peserta didik itu sendiri. Dari berbagai hal yang diperoleh dari penyediaan fasilitas tersebut, salah satu yang tercipta adalah adanya perkembangan intelektual. Dalam perkembangan intelektual, terdapat satu bagian yaitu hasil belajar. Dalam hasil belajar terdapat perkembangan intelektual/kecerdasan yang dapat dinyatakan dalam bentuk skor/nilai.

\section{SIMPULAN DAN SARAN}

\section{Kesimpulan}

1. Pengelolaan kelas berpengaruh positif terhadap hasil belajar IPS kelas IV SDN Kecamatan Belawa Kabupaten Wajo sebesar 93,12\% hal ini disebabkan karena pengelolaan kelas oleh para guru sudah efektif.

2. Pemanfaatan sarana dan prasarana berpengaruh Negatif terhadap hasil belajar IPS kelas IV SDN Kecamatan Belawa Kabupaten Wajo sebesar $27,6 \%$. Koefisien bernilai negative artinya jika tidak ada pemanfaatan

3. Belawa Kabupaten Wajo sebesar $(93,12 \%)$, sedangkang pemanfaatan sarana dan prasarana mempunyai pengaruh sebesar $-27,6 \%$.

\section{Saran}

Berdasarkan hasil penelitian dan pembahasan serta kesimpulan yang telah dikemukakan, berikut ini adalah beberapa saran yang diharapkan dapat menjadi masukan dan bahan pertimbangan untuk penelitian selanjutya, adapun saran tersebut berikut ini:

1. Bagi Guru diperlukan pengelolaan kelas dan pemanfaatan sarana dan prasarana yang lebih efektif dan efesien lagi agar hasil belajar peserta didik semakin meningkat. Pengelolaan kelas dan pemanfaatan sarana dan prasarana tidak hanya terbatas dari ketersediaan dari sekolah tetapi juga bisa di sediakan oleh para guru sekreatif mungkin agar hasil belajar peserta didik lebih meningka.

2. Para Kepala Sekolah Di SD Sekecamatan Belawa untuk mengembangkan pengelolaan kelas dan lebih memperhatikan segala sarana dan parasarana yang dapatC menunjang keberhasilan terwujudnya hasil belajar yang semakin membaik dari tahun ke tahun.

3. Dinas Pendidikan Kabupaten Wajo Diharapkan agar meningkatkan kreatifitas guru terhadap pengelolaan kelas dan lebih meningkatkan lagi sarana dan prasarana di sekolah-sekolah agar prestasi dan hasil belajar peserta didik semakin meningkat

4. Bagi peneliti lain, penelitian ini dapat digunakan sebagai bahan rujukan atau acuan untuk melakukan penelitian selanjutnya. Apabila ingin melakukan penelitian yang sejenis sebaiknya penelitian ini, lebih dikembangkan secara lengkap dengan subyek yang berbeda serta lebih mengembangkan variabel, sub variabel dan indikatornya

\section{DAFTAR RUJUKAN}

Arikunto, S. (1997). Prosedur Penelitian Revisi V.Jakarta: PT Rineka Cipta.

Arikunto, S. (2009). Dasar-dasar Evaluasi Pendidikan. Jakarta: Bumi Aksara.

Bafadal, I. Manajeman Perlengkapan Sekolah Teori dan Aplikasinya: Bumi Aksar. Jakarta. 2014

Barnawi \& Arifin,M. 2014. Manajemen Sarana dan Prasarana Sekolah. Jogjakarta: Ar Ruzz Media.

Depdiknas. 2007. Naskah Akademik Kajian Kebijakan Kurikulum Mata Pelajaran Ilmu. Bandung: Pustaka setia.

Mulyani Sumantri \& Johar Permana. (1999). Strategi Belajar Mengajar. Yogyakarta: Dirjendikti. 
Sitti Hajeriani. Pengaruh Pengelolaan Kelas, Pemanfaatan Sarana Dan Prasarana Terhadap Hasil Belajar IPS Pada Peserta Didik Di Kelas IV SDN Se-Kecamatan Belawa Kabupaten Wajo

Mustari, M. Manajemen Pendidikan. Raja Grafindo Persada. Jakarta. 2014

Moh. Uzer Usman. (2006). Menjadi Guru Profesional. Bandung: PT. Remaja Rosdakarya.

Permendiknas Nomor 24 Tahun 2007 Tentang Standar Sarana Dan Prasarana Sekolah/Madrasah Pendidikan Umum.

Rusdhye, S. (2011). Prinsip-prinsip Manajemen Kelas. Jogjakarta: Diva Pres.

Susanto, (2013). Teori Belajar \& Pembelajaran di Sekolah Dasar. Jakarta: kencana.

Sugiyono. 2014. Metode Penelitian Kuantitatif, Kualitatif, Dan $R \& D$. Bandung: Alfabeta.

Sugiyono. (2009). Metode Penelitian Pendidikan. Bandung: Alfabeta

Syaiful Bahri Djamarah \& Aswan Zain. (2010). Strategi Belajar Mengajar. Jakarta: Rineka Cipta.

Sahabuddin. (2007). Mengajar dan Belajar. Makassar: Badan Penerbit UNM.

Susanto, A. (2014), Teori Belajar dan Pembelajaran di Sekolah Dasar. Kencana Prenada Media Group Jakarta.

Tri Mulyani.W, V. (2001). Pengelolaan Kelas (Classroom Management). Yogyakarta.

Tim Penyusun Program Pascasarjana UNM. 2014. Pedoman Penulisan TesisMakassar: Panrita Press Unismuh Makassar. 